\title{
Towards Eco-efficient Lean Production Systems
}

\author{
Francisco Moreira, Anabela C. Alves, and Rui M. Sousa \\ Production and Systems Engineering Department \\ University of Minho, Campus of Azurém, 4800-058 Guimarães, Portugal \\ fmoreira@dps.uminho.pt, anabela@dps.uminho.pt, rms@dps.uminho.pt
}

\begin{abstract}
Lean Production has proved itself a worthwhile production strategy in many distinct industries across all regions of the planet by achieving higher levels of production efficiency. Several authors identified that Lean inadvertently has had significant environmental gains. Such achievements are considered of special relevance in a global and highly competitive economy which is progressively both tied-up and driven by an environmental agenda. The main goal of the present study is to enlighten the contribution of Lean for achieving a better environmental performance of production systems and identify this as an emergent business model for supporting eco-efficiency.
\end{abstract}

\section{Introduction}

Lean is a world leading production strategy that has proved its worthiness in industrial environments over a long period of time. It worked well when mass production was predominant by delivering goods in an affordable way. Lean ultimately outpaced it when costumers begun to change their needs and demanded increasingly customized and high quality products at competitive costs. More recently, new issues have been raised to the agenda and companies begun to rethink their purpose and strategies, so that more value could be added while contributing to social equity and preventing environmental burdens. Lean is a production strategy whose fundamental principles drive the industry towards a more effective production of goods and services. The eco-efficiency concept is primary to sustainable development and intends to provide more value with less environmental impact. This could be regarded, as "doing more with less" which is a well known saying in Lean Thinking. This is translated into operational terms by a systematic and continuous elimination of waste. However, Lean methods seem not to explore nor put much emphasis on environmental gains, nor in quantifying them. Does Lean make in fact a positive contribution towards greener production of goods and services? Could Lean Production benefit from a more clear endorsement of environmental issues?

The aim of this study is to identify and explore the contributions of Lean to reduce environmental impacts that naturally result from industrial activity. This is accomplished through a literature review followed by a critical discussion.

\section{Literature Review}

\subsection{Lean Production}

The Lean Production concept was coined in 1988 by Krafcik [1], based in TPSToyota Production System [2] and was widely disseminated by several projects of the 
IMVP-MIT program [3], [4, [5]. The reason for this interest in the Japanese automotive industry was the excellent set of results achieved by the Toyota factories, since the oil crises in 1973, in designing and building cars in less time with fewer people and lower inventories. TPS is based on principles and techniques of Just-in-Time (JIT) production and on continuous improvement - "Kaizen" [6], [7]. Lean Production aims to achieve, for a large diversity of products, high productivity and, simultaneously, synchronization of production and demand. To attain these objectives, five principles were established: (i) create value for the customer, (ii) identify the value stream, (iii) create flow, (iv) produce only what is pulled by the customer, and (v) pursuing the perfection by continuous identification and elimination of waste. These principles are part of the Lean Thinking concept [4] which is focused on waste, or "muda", elimination. Waste is everything that does not directly contributes for adding value to a product, under the perspective of customers' needs and requirements, being identified seven main types: defects, inventory, over-processing, waiting, motion, transportation and overproduction. Overproduction means produce more than the demand, and, probably, is the worst waste due to its implications, e.g. overstaffing and excessive inventory, along with the associated costs. Due to their visibility, usually the defects are easily identified (by inspection) within the manufacturing process. They are the major concern of any quality department and may imply rework (if the defective parts can be fixed) or disposal (if the defects are unrecoverable). Inventory means raw material, WIP (Work In Process), or finished goods spread all over the shop-floor and warehouses, frequently hiding real problems like production imbalances, suppliers that do not accomplish the deliveries' due dates, long setup times, defects and machines breakdowns. This causes longer lead times, risk of obsolescence and/or deterioration of goods, transportation and storage costs, and delays. Overprocessing, or incorrect processing, is another kind of waste, resulting from unnecessary or incorrectly processed operations due to wrong methods or inadequate tools. The main consequences are the potential occurrence of defects and the waste of time and material. The waiting waste happens when operators are stopped waiting for parts, machines or other colleagues. Motion and transportation are associated to operators' movements and transport of materials, respectively. Besides the previously referred wastes, Liker [8] considers an additional type: unused operators' creativity. When properly stimulated, operators can improve, better than anyone, the process they are working on. In fact, the creative thinking was pointed out by TPS as one of its pillars [2].

\subsection{Eco-efficiency}

Back in 1991, the Business Council for Sustainable Development (BCSD) coined the term eco-efficiency while preparing a document that would serve as an input for the Earth Summit held in Rio de Janeiro in 1992. The eco-efficiency concept was first published in 1992 by Stephan Schmidheiny and BCSD in the book "Changing Course". The World Commission on Environment and Development (WCED) refers that eco-efficiency was sought to encapsulate the business goal of promoting sustainable development, i.e. a development model that meets present human needs without compromising wealth of future generations [9]. According to BCSD, eco-efficiency is "The delivery of competitively priced goods and services that satisfy human needs 
and bring quality of life, while progressively reducing ecological impact and resource intensity throughout the life cycle, to a level at least in line with the Earth's estimated carrying capacity." [10]. The concept was envisaged after recognition that the growth in human population, associated with the strong environment impact of their activity, threatens the future of new generations of human beings and of other species. Eco-efficiency concept translates the simple idea of "creating more with less" by: (i) reducing materials intensity; (ii) minimizing energy intensity in both products and services; (iii) reducing the quantity and the dispersion of toxic substances and decreasing the level of toxicity of such substances; (iv) promoting recycling and the use of renewable energy; (v) extending the durability of products, and; (vi) increasing service intensity. Akin to eco-efficiency is the need to provide genuine goods and services that consumers truly treasure and fully benefit while minimizing the full environmental impact, i.e. the impacts resulting from resources origins to product disposal. This might be regarded as a full perspective of the impact of such goods and services, from a cradle-to-grave perspective [11]. Eco-efficiency uses both a recurrent step-by-step process improvement and a radical innovation process, and can be applied to products and processes. Industrial symbiosis is also stimulated so that aggregated impacts (multiple companies) are lowered. Eco-efficiency concept has been disseminated through the works of the WBCSD (World Business Council for Sustainable Development). This coalition gathers contributions from about 200 international companies from about 20 major industrial sectors.

Several other contributions, akin to eco-efficiency concept, have been made in the past by many other individuals and organizations. For the purpose of this paper, those contributions were considered to be aligned to eco-efficiency goals, and, should be regarded as an aggregated body of concepts that push forward the vision of progressing mankind footprint. These other contributions, such as works and concepts, will be shortly referred and presented next.

United Nations Environment Programme (UNEP) launched their Cleaner Production Programme in 1989, and intended "the continuous application of an integrated preventive environmental strategy applied to processes, products and services to reduce risks to humans and the environment" [12]. This was partnered by United Nations Industrial Development Organization (UNIDO) from 1994 onwards and has resulted in the establishment of multiple country-wide Clean Production Programmes. WBSCD and UNEP recognize that eco-efficiency and cleaner production programme are complementary, and reinforce mutually while sharing the same goal of sustainable development [13].

Weizsäcker [14] describe a world of waste and propose an efficiency cure. McDonough and Braungart [15], authors of the Cradle-to-Cradle concept, expressed the need for an emerging and novel industrial revolution, one that might be grounded on both human creativity and cooperation, and on natures' design effectiveness. According to these authors, consumers, environmentalists and industry, have long time antagonistic perspectives: conventional industrial processes (extraction, production, disposal), along with a never ending demand for economic growth, have been regarded as highly damaging to the ecosystems; environment defenders represent often an obstacle to production and growth; consumers have difficulty to restrain their increasing consumption behavior. They acknowledge that "most industrial processes are unintentionally depletive" and that crude products, i.e. "...products that are not designed particularly for human and ecological health are unintelligent and inelegant", 
persist in our daily life as outcomes of outdated and unintelligent design. These authors propose a new eco-effectiveness concept for, more than progressing present status, making a radical change in the way products are designed, produced and used.

Other concepts, such as: Industrial Ecology, Green Production, Sustainable Engineering, Design for the Environment, Industrial Metabolism, among others, seem targeted at making a positive contribution to sustainable development.

\subsection{Lean and Green}

The creativity stimulus and the continuous improvement have an important role in promoting a culture of pursuing perfection. The companies that embrace this culture

Table 1. Publications about Lean and Green relationship

\begin{tabular}{|c|c|c|}
\hline Date & Authors & Publication title \\
\hline 1993 & Maxwell et al. & $\begin{array}{l}\text { "Does lean mean green?: The implications of lean production for } \\
\text { environmental management" }\end{array}$ \\
\hline 1996 & Florida, R. & $\begin{array}{l}\text { "Lean and green: the move to environmentally conscious } \\
\text { manufacturing" }\end{array}$ \\
\hline 1997 & Helper et al. & Can Green be Lean? \\
\hline 1998 & Maxwell et al. & $\begin{array}{l}\text { Case study: Honda of America Manufacturing, Inc.: Can lean } \\
\text { production practices increase environmental performance? }\end{array}$ \\
\hline 1999 & Pojasek, R. & $\begin{array}{l}\text { Quality toolbox: Five S's: A tool that prepares an organization for } \\
\text { change. }\end{array}$ \\
\hline 1999 & Pojasek, R. & Quality toolbox: Poka-yoke and zero waste \\
\hline 1999 & Pojasek, R. & Quality toolbox: Zeroing in \\
\hline 1999 & Waldrip, G. & Integrating the Elements of Sustainable Manufacturing \\
\hline 2000 & $\begin{array}{l}\text { Wlodarczyk et } \\
\text { al. }\end{array}$ & $\begin{array}{l}\text { Using a systems approach to improve process and environmental } \\
\text { performance }\end{array}$ \\
\hline 2000 & U.S. EPA & $\begin{array}{l}\text { Pursuing perfection: Case studies examining lean manufacturing } \\
\text { strategies, pollution prevention, and environmental regulatory } \\
\text { management implications. }\end{array}$ \\
\hline 2000 & Klassen, R.D. & $\begin{array}{l}\text { Just-in-time manufacturing and pollution prevention generate } \\
\text { mutual benefits in the furniture industry. }\end{array}$ \\
\hline 2001 & $\begin{array}{l}\text { Rothenberg et } \\
\text { al. }\end{array}$ & $\begin{array}{l}\text { Lean, green, and the quest for superior environmental } \\
\text { performance. }\end{array}$ \\
\hline 2002 & \begin{tabular}{|l|}
$\begin{array}{l}\text { Soltero and } \\
\text { Waldrip }\end{array}$ \\
\end{tabular} & Using Kaizen to Reduce Waste and Prevent Pollution \\
\hline 2003 & U.S. EPA & $\begin{array}{l}\text { Lean manufacturing and the environment: Research on advanced } \\
\text { manufacturing systems and the environment and recommendations } \\
\text { for leveraging better environmental performance. }\end{array}$ \\
\hline 2004 & $\begin{array}{l}\text { Larson and } \\
\text { Greenwood }\end{array}$ & $\begin{array}{l}\text { Perfect Complements: Synergies between Lean Production and } \\
\text { Eco-Sustainability Initiatives }\end{array}$ \\
\hline 2007 & U.S. EPA & The Lean and Environment Toolkit \\
\hline 2008 & U.S. EPA & The Lean and Energy Toolkit \\
\hline 2008 & Pojasek, R. B. & Quality Toolbox: Framing your Lean-to-Green effort \\
\hline 2009 & Found, P. & Lean and Low Environmental Impact Manufacturing \\
\hline 2010 & Yang et al. & $\begin{array}{l}\text { Mediated effect of environmental management on manufacturing } \\
\text { competitiveness: An empirical study }\end{array}$ \\
\hline
\end{tabular}


are always aware to find the wastes referred in section 2.1, in all their activities. So, it is natural that besides these wastes several others had been identified, such as excessive use of energy and materials [16], and emissions of pollutants into the air, water and land [17]. Nevertheless the efforts to reduce waste should be associated not only to the production process, but also to the product design "...a vehicle that can make the air cleaner than it is..." and "In my vision for the future, the most important themes are the environment, energy,..." (Toyota president, cited in [18]. According to the literature, Lean implementations seem to, unintentionally, reveal interesting environmental performances, while its methods resemble environmental management systems [17] which have been published at least since 1993, as shown in Table 1.

Several individual authors and organizations have researched the relationship between Lean and environmental performance - eco-efficiency, as the authors put it starting in 1993, just a year after the eco-efficiency concept was disseminated. The issue was therefore subject of reflection for about two decades. The 1990s is not as much as rich on publications on the subject as it is the second decade of 2000s. Lean paradigm concept dissemination to Western economies had a great impulse after the first IMVP publications on the subject after 1990. This explains the early works, published not long time after, which attempted to relate Lean to environmental impacts. Some other publications about Lean Production, like [16], even without formally address the mentioned relationship, refers the energy waste as something to eliminate. On the other hand, publications in journals like Business Strategy and Environment [19], [20], [21] or Corporate Social Responsibility and Environmental Management, have appealed to a urgent need to implement management policies or to create sustainable supply chains that promotes best practices in environment [22].

\section{Discussion}

Based in Lean industrial case studies and in principles and methods akin to Lean Production, most studies refer that Lean continuously improves resource productivity, therefore decreasing products' intensity in both materials and energy (two fundamental aspects of eco-efficiency). Although not specifically addressed, it seems rather logic that dispersion of toxic substances is generally improved, deriving from lower use of raw materials. In terms of improvements in the levels of toxicity of substances used, the review is not conclusive. The EPA (Environmental Protection Agency) report, dated 2003 [17], suggests that Lean might not be addressing adequately such issue. Design for manufacturing method was spotted a potential source for improving recyclability levels, since it normally results in lower number of different materials used. Along with materials type identification and marks to facilitate dismantling, this would easy materials separation and dismantling tasks at end-of-life.

Overall, there is strong evidence that the scientific community holds a positive opinion on the real impact of Lean on improved environmental performance of production systems. This is particularly truth for continuous improvement culture and waste reduction. Figure 1 illustrates, by way of a cause-effect diagram (Ishikawa diagram), the origins and implications of waste within production systems. 


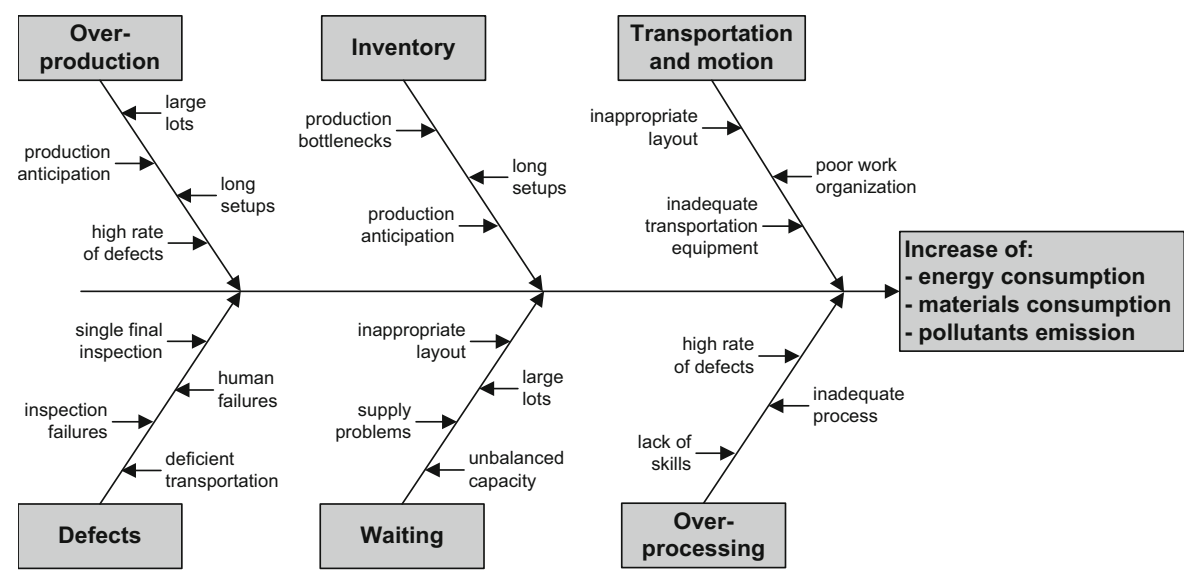

Fig. 1. Production wastes as causes of weak environmental performance

This diagram (Figure 1) includes the main causes of each type of waste providing thus valuable hints on how to reduce them. For example, the reduction of equipments' setup time (by applying the SMED methodology - Single Minute Exchange of Die) contributes to reduce both overproduction and inventory. These reductions naturally lower the energy and materials consumption while reducing the emissions. Figure 2 show the main effects of each production waste.
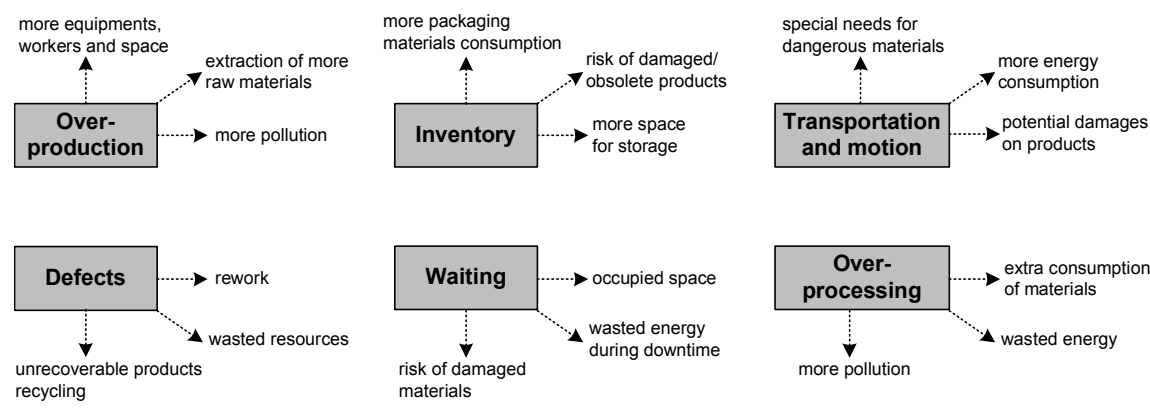

Fig. 2. Effects of the production wastes

All the consequences resulted from the 6 waste types, illustrated in figure 2, can be detailed within the previous classes of environmental impact, namely: energy use, materials consumption and emissions (Figure 1). For example, supplementary energy is required to produce the extra products which are above the required quantity (overproduction), thus resulting in added energy for: (i) extraction and conversion of natural resources into raw material; (ii) transportation of the raw materials to the shop floor; and, (iii) processing of the raw materials into the extra products at the shop floor. While the third consequence is positioned at the second stage of the products' life-cycle (production) and derives directly from overproduction, the first two are 
secondary (or indirect) consequences to the problem of overproduction, and are positioned within the first stage of products' life-cycle (extraction and processing of raw materials). Naturally most of environmental effects are consequence of more than one production waste. In fact, all production wastes have a direct or indirect impact on each of the three sub-classes of effects represented in Figure 1. In order to map such impacts and to improve the environmental performance some authors have been adapting some Lean Production tools, such as Five S, Poka-Yoke mechanisms, Kaizen, Visual Stream Mapping [23], [24], [25], US-EPA, 2007, US-EPA, 2008.

Some examples have been found that negatively contrast Lean against environmental performance, namely by improved quality and durability by way of using more toxic chemicals to ensure higher rust-proofing [26], and the use of more frequent trips for delivery of materials [27] which result in increased Greenhouse Gas (GHG) emissions. Wider implications of Lean improvements within full products' life-cycle seem not yet fully studied and understood. LCA impact assessment is for that purpose suggested [28].

\section{Conclusion}

A literature review has been conducted to investigate the causal relationship between Lean Production and eco-efficiency, i.e. the use of a specific production strategy for achieving superior environmental performance. Several individual authors and organizations have researched this relationship in the last two decades. The studies are essentially based on industrial case studies and on conceptual relationships given Lean principles and methods. Few environmental drawbacks that can be attributed to Lean production were found in literature. On the other hand, most of the studies that found a causal relation between Lean and Eco-efficient production systems are highly positive in their findings, resulting in strong evidence that Lean has in fact a positive contribution in the improvement of the environmental performance. This contribution is done in a multitude of aspects, both in direct and secondary forms. Although relevant, the positive contribution was identified to be non-intentional or at least not strategic, since the DNA pattern of Lean methods was not identified within this contribution, i.e. it is not reported, neither clearly measured nor specifically addressed. In terms of future research, the authors intend to progress further the research on the Lean-to-Green relationship and to adapt Lean Production tools to promote production cleanliness.

\section{References}

1. Holweg, M.: The genealogy of Lean Production. Journal of Operations Management 25(2007), 420-437 (2007)

2. Monden, Y.: Toyota Production System - an integrated approach to just-in-time, 3rd edn. Engineering and Management Press, Institute of Industrial Engineers (1998)

3. Womack, J., Jones, D., Roos, D.: The machine that changed the world. Rawson Associates (1990)

4. Womack, J., Jones, D.: Lean Thinking. Siman \& Schuster, New York (1996) 
5. Womack, J.: Lean solutions: how companies and costumers can create value and wealth together. Simon \& Schuster, London (2005)

6. Imai, M.: KAIZEN - the key to Japan's Competitive Success. McGraw-Hill, Irwin (1986)

7. Imai, M.: Gemba Kaizen: a common sense low-cost approach to management. McGrawHill, New York (1997)

8. Liker, J.: The Toyota Way: 14 Management Principles from the World's Greatest Manufacturer. McGraw -Hill, New York (2004)

9. WCED, Our Common Future. Report of the World Commission on Environment and Development, United Nations (1987),

http: //worldinbalance.net/intagreements /1987-brundtland.php (accessed February 20, 2010)

10. WBCSD, Eco-Efficiency and Cleaner Production: Charting the course to sustainability (1996)

11. Hendrickson, C., Lave, L., Matthewsal, S.: Environmental Life Cycle Assessment of Goods and Services: An Input-Output Approach, Resources for the Future (2006)

12. UNEP, Cleaner Production: a training resource package, first edition (1996), http://www.uneptie.org/shared/publications/pdf/WEBx0029xPA-CPtraining.pdf (accessed February 20, 2010)

13. WBCSD/UNEP, Cleaner Production and Eco-efficiency: Complementary approaches to sustainable development. WBSCD and UNEP edition (1998)

14. Weizsäcker, E., Lovins, A., Lovins, L.: Factor Four: Doubling Wealth-Halving Resource Use. Earthscan Publications Ltd. (1997)

15. McDonough, W., Braungart, M.: Cradle to cradle: Remaking the way we make things. North Point Press (2002)

16. James-Moore, S.M., Gibbons, A.: Is lean manufacture universally relevant? An investigative methodology. International Journal of Operations and Production Management 17, 899-911 (1997)

17. U.S. EPA, Lean manufacturing and the environment: Research on advanced manufacturing systems and the environment and recommendations for leveraging better environmental performance. United States Environmental Protection Agency (2003)

18. Stewart, T.A., Raman, A.P.: Lessons from Toyotas's long drive. Harvard Business Review (2007)

19. Bragd, A., Bridge, G., Hond, F., Jose, P.D.: Beyond Greening: New Dialogue And New Approaches For Developing Sustainability. Business Strategy and the Environment 7, 179-192 (1998)

20. Korhonen, J., von Malmborg, F., Strachan, P.A., Ehrenfeld, J.R.: Management and Policy Aspects of Industrial Ecology: An Emerging Research Agenda. Business Strategy and the Environment 13, 289-305 (2004)

21. Anttonen, M.: Greening from the Front to the Back Door? A Typology of Chemical and Resource Management Services. Business Strategy and the Environment (2008)

22. Gold, S., Seuring, S., Beske, P.: Sustainable Supply Chain Management and InterOrganizational Resources: A Literature Review. Corporate Social Responsibility and Environmental Management (2009)

23. Pojasek, R.B.: Quality toolbox: Five S's: A tool that prepares an organization for change. Environmental Quality Management 9(1), 97-103 (1999a)

24. Pojasek, R.B.: Quality toolbox: Poka-yoke and zero waste. Environmental Quality Management 9(2), 91-97 (1999b) 
25. Soltero, C., Waldrip, G.: Using kaizen to reduce waste and prevent pollution. Environmental Quality Management 11(3), 23-38 (2002)

26. Helper, S., Rozwadowski, H., Clifford, P.G.: Can Green Be Lean? Academy of Management Annual Meeting, Organizations and the Natural Environment (1997)

27. Katayama, H., Bennet, D.: Lean production in a changing competitive world: a Japanese perspective. International Journal of Operations \& Production Management 16(2), 8-23 (1996)

28. Hollie, S.: Solutions to Health Care Waste: Life-Cycle Thinking and "Green" Purchasing. Environmental Health Perspectives 109, 205-207 (2001) 